\section{Investigation of germ caused by Guillain-Barré syndrome in poultry meat products in North West of Iran}

\section{Vadood Razavilar, Davoud Nassiri}

Department of Food Hygiene, Science and Research Branch, Islamic Azad University, Tehran, Iran

\begin{abstract}
Campylobacter species are the most important pathogens that cause bacterial gastroenteritis being spread through food with animal origin. Given such fact, the current study aimed at investigate the prevalence of Campylobacter based on phenotypic and genotypic analysis of poultry meat and edible offal in Western Azerbaijan. To conduct the study, a total of 552 chicken samples including meat (samples), liver (138 samples), gizzard (138 samples) and hearts (138 samples) were randomly collected from poultry slaughterhouses at West Azerbaijan province from April 2014 to September 2014. Based on the culture tests, 208 samples $(37 / 7 \%)$ were contaminated with Campylobacter species. The highest range of Campylobacter species out breaks was observed in poultry liver $(49 / 2 \%)$, followed by gizzard $(42 / 8 \%)$, heart $(33 / 3 \%)$ and meat $(25 / 4 \%)$. Among the isolated Campylobacter, C. jejuni was the most prevalent $(78 / 4 \%)$ and the rest were C. coli species $(21 / 6 \%)$. All 208 species of Campylobacter isolated as $C$. jejuni and $C$. coli from species culturing were also approved by m.PCR. The results of the study pinpointed to the chicken edible offal importance as a potential source of Campylobacterial contaminations.
\end{abstract}

\section{Introduction}

Campylobacteriosis, serving as an important common disease, shoulders a major role in infectious gastroenteritis in humans and is considered as the world's first cause of gastroenteritis followed by dysentery and diarrhea and other complications such as meningitis, Guillain Barre syndrome and cholecystitis. ${ }^{1,2}$

Digestive disorders and diarrhea caused by the bacterial Campylobacter is among the common illnesses primarily in developing countries, and 5 to 15 percent of diarrhea in these countries are instigated by the bacteria, and the prevalence of the bacteria as a cause of diarrhea in our country has been reported to be from 2 to $10 \%,{ }^{3}$ and even the primary cause of death in developed countries, especially among children under 5 in the United States, was attributed to such bacteria in that two million cases of bacterial infection are reported each year. ${ }^{2}$

The bacteria which was first discovered in the nineteenth century by Theodor Escherichia a gram-negative, spiral-shaped or curved, growing and multiplying at Microaerophilic conditions at a temperature of $42^{\circ} \mathrm{C}$, and below $25^{\circ} \mathrm{C}$, it stops growing and multiplying but does not disappear. ${ }^{2}$ The thermophilic Campylobacter species, such as Jejuni and Coli, have an important role in the development of Campylobacteriosis becoming more prominent in the food infection as the spread of Campylobacter contamination in food has become very important in recent years going even further than Salmonella. ${ }^{2}$ Studies show that the bacterium originates mainly from food with animal resource. Moreover, raw milk, meat and poultry, untreated surface water and edible fungi are the sources of infections with Campylobacteriosis disease being common in spring and summer. Infections with Campylobacter have been reported in several countries in broiler chickens, so that the bacteria survived during the slaughtering process and were transmitted to uninfected poultry organs. ${ }^{2}$ Due to its high sensitivity and detection speed, the PCR method has the potentiality to determine if there is even a bacterium per $\mathrm{ml}$ and reaches the response in a very short time. Many studies have examined the prevalence of the bacteria in meat and poultry as well as diarrheal samples. ${ }^{4}$ The consumption of half-baked meat and the related products serves as the main source of human infection although other livestock meat and milk products are potential sources of the disease. There are reports on the prevalence of Campylobacter among live birds and animals and different kinds of food from all over the world revealing upon a wide range of results. Previous reports highlighted the infection in chickens from zero to $100 \%$ which was up to $60 \%$ for the cows. The prevalence of the infection in poultry given to the market have been reported to be $100 \%$ and lower incidences of other animals meat were also given., 6 Although there are many studies casting light on the prevalence of Campylobacter species among poultry in Iran, ${ }^{7-10}$ and other countries including Korea, ${ }^{11}$ Japan, ${ }^{6}$ Canada, ${ }^{12}$ Ireland, ${ }^{13}$ Pakistan, ${ }^{14}$ Belgium, ${ }^{15}$ little data existed on the poultry meat biproducts infection including liver, gizzard and heart in Iran, therefore, the study aimed at evaluating the contamination of these products.
Correspondence: Vadood Razavilar, Department of Food Hygiene, Science and Research Branch, Islamic Azad University, Tehran Province, Tehran, Hesarak, Iran. E-mail: vrazavi@ut.ac.ir

Key words: Campylobacter, Poultry Meat, Edible Offals, m-PCR.

Contributions: the authors contributed equally.

Conflict of interest: the authors declare no potential conflict of interest.

Received for publication: 22 July 2017.

Revision received: 20 August 2017.

Accepted for publication: 17 September 2017.

This work is licensed under a Creative Commons Attribution NonCommercial 4.0 License (CC BY-NC 4.0).

CCopyright V. Razavilar and D. Nassiri, 2017 Licensee PAGEPress, Italy

Microbiology Research 2017; 8:7328

doi:10.4081/mr.2017.7328

\section{Materials and Methods}

To conduct the study, a total of 552 samples including chicken meat (138 samples), liver (138 samples), gizzard (138 samples) and hearts (138 samples) were randomly collected from poultry slaughterhouses at West Azerbaijan province from April 2014 to September 2014and were transferred to the laboratory for analysis aiming at investigating the presence of Campylobacter species in cold temperature. To determine the phenotype of bacteria, 10 grams of the sample was added to a bag with one hundred $\mathrm{mL}$ broth Preston (Preston enrichment broth base, Himedia, Mumbai, India, m899) containing five percent defibrinated sheep blood for enrichment. The bags were incubated for 24 hours at $42^{\circ} \mathrm{C}$ in carbon dioxide presence. Then, the liquid in the bag was removed by a sterile loop and cultured on specific Campylobacter selective Agar (Himedia, Mumbai, India, m994) as a separate line to obtain single separated colonies. Then, it was incubated for 48 hours (Co2 10\% v/v) at $42^{\circ} \mathrm{C}$. After the initial plate analysis, the suspected colonies were stained with Gram's stain and upon the curved bacteria resolution, the re-culturing was also applied. Upon obtaining the colonies, the biochemical tests including catalase, Indoxyl acetate hydrolysis were used and in order to differentiate between the two species Jejuni and Coli hippurate hydrolysis 
test was conducted, which was positive for Jejuni. ${ }^{1}$

To investigate the Campylobacter genotypic, DNA extraction and Multiplex PCR method were applied. Using the culturing method and DNA extraction kit (Cina Gen, Iran), the confirmed colonies DNA were extracted according to the Kit manufacturer's instructions. The PCR test in this study followed Denis et al. procedure. ${ }^{16}$ For PCR reaction, the reaction final volume of 25 microlitres was considered including $20 \mathrm{ng}$ DNA template, $2 \mathrm{mM} \mathrm{MgCl} 2,25 \mathrm{pmol}$ of each primer, a single Taq polymerase enzyme and $200 \mathrm{mM}$ mixed dNTP. The size of PCR products corresponding to each sample is given below. To confirm the presence of the multiplied sample, 20 microlitres of PCR was paced on electrophoresis with $1 / 5$ percent agarose gel containing ethidium bromide in the presence of $100 \mathrm{bp}$ DNA marker in constant voltage of 80 volts (Table 1).

\section{Results}

The current study aimed at evaluating Campylobacter phenotypic and genotypic outbreaks in chicken meat and its edible offal at West Azerbaijan province, Iran. To conduct the study, a total of 552 samples including chicken meat (138 samples), liver (138 samples), gizzard (138 samples) and hearts (138 samples) were randomly collected from poultry slaughterhouses at West Azerbaijan province from April 2014 to September 2014 and were transferred to the laboratory for analysis aiming at investigating the presence of Campylobacter species in cold temperature.

Based on the culture tests, 208 samples $(37 / 7 \%)$ were infected with Campylobacter species. The highest range of Campylobacter species outbreaks was observed in poultry liver $(49 / 2 \%)$, followed by gizzard $(42 / 8 \%)$, heart $(33 / 3 \%)$ and chicken meat (25/4\%). Among the isolated
Campylobacter, the Jejuni type was the most prevalent $(78 / 4 \%)$ and the rest were of Coli type $(21 / 6 \%)$. All 208 species of Campylobacter isolated as Jejuni and Coli types from culturing were also approved by multiplex polymerase chain reaction test (m.PCR). A statistically significant difference $(\mathrm{P}<0.05)$ was observed in Campylobacter species outbreak in meat samples taken in summer $(40 / 9 \%)$. The results are presented in Tables 2-4 and in Figure 1.

\section{Discussion}

The given result shows 208 samples (37/7\%) were infected with Campylobacter species. Previous studies in Iran have reported the contamination level to the bacteria for different cities as Isfahan with 56/1 percent, ${ }^{8}$ Shahrekord with 47 percent, ${ }^{7}$ Tehran with $63 / 2 \%$ and $49 / 5 \%,{ }^{9}$ and Mashhad with $76 \%{ }^{17}$

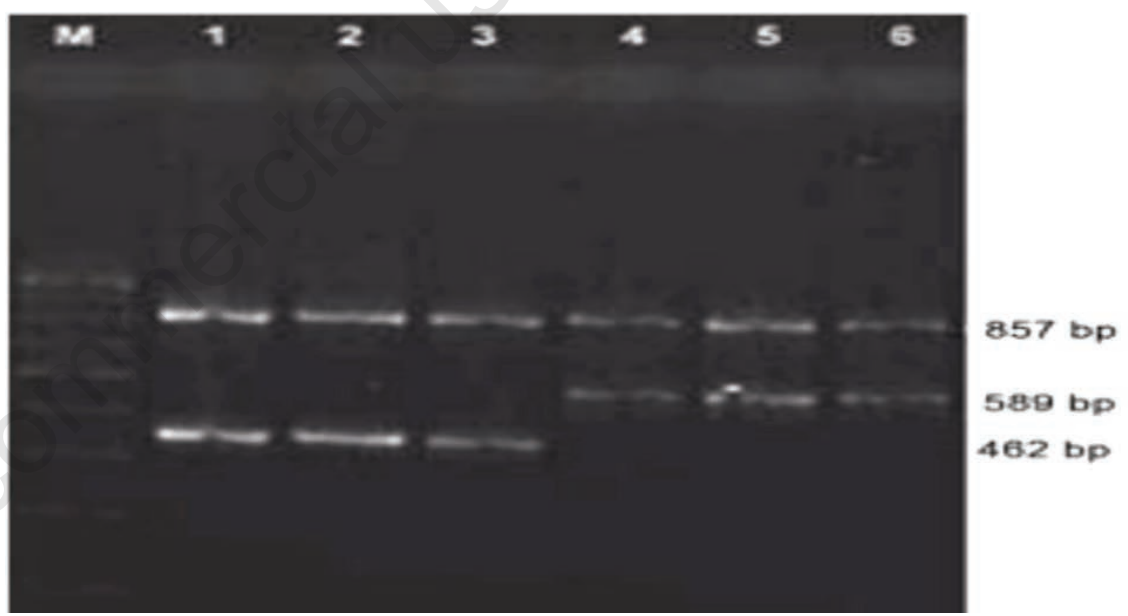

Figure 1. Multiplex PCR amplicons on 1.5\% agarose gel. Lane M: 100 bp ladder; Lane: 1, 2, 3 - C. coli; Lane: 4, 5, 6 - C. jejuni.
The outbreak of Campylobacter species in chicken meat in other countries also suggests a contamination level of 30 to 90 percent. The contamination levels in different countries were as follows: Turkey with $92 / 8 \%,{ }^{18}$ Korea with $68 / 3 \%,{ }^{11}$ Canada with $62 / 4 \%,{ }^{12}$ Japan with $60 \%,{ }^{6}$ Ireland with $49 / 90 \%,{ }^{13}$ and Pakistan with $48 \% .^{14}$ Despite having many studies reporting the prevalence of Campylobacter species contamination in poultry, there are few studies highlighting on the edible offal contamination to the bacteria.

A similar study conducted by Rahimiin 2006 and 2008 casted light on the prevalence of Campylobacter in the chicken liver marketed in Isfahan. Accordingly, the contamination of 205 samples under study was reported to be $49 / 3 \%$, and the liver contamination for the, chicken, turkey and ostrich were $49 / 3 \%, 40 \%$ and $16 / 7 \%$, respectively. ${ }^{8}$ Also, Shakerian et al. ${ }^{19}$ in a study on evaluating the Campylobacter contamination in poultry liver in Shahrekord indicated that

Table 1. Sequences of primers used for detecting Campylobacter and the related Jejuni and Coli species.

$\begin{array}{lll}\text { Gene } & \text { Primer consequence } & \text { Type of product } \\ \text { 16SrRNA } & \text { MD16S1 Upper Primer } & \text { 857 bp for Campylobacter genus } \\ & \text { 3 ATC TAA TGG CTT AAC CAT TAA AC5 } & \\ & \text { MD16S1 Lower Primer } & \\ \text { mapA } & \text { 3GGA CGG TAA CTA GTT TAG TAT T } 5 & 589 \text { bp for } \text { C. jejuni } \\ & \text { MDmapA1 upper Primer } & \\ & \text { 3CTA TTT TAT TTT TGA GTG CTT GTG } 5 & 462 \text { bp for C. coli } \\ \text { CeuE } & \text { MDmapA2 Lower Primer } & \\ & \text { 3GCT TTA TTT GCC ATT TGT TTT ATT A5 } & \\ & \text { COL3 Upper Primer } & \\ & \text { 3AAT TGA AAA TTG CTC CAA CTA TG5 } & \text { MDCOL2 Lower Primer } \\ \end{array}$


259 samples of 400 samples $(64 / 8 \%)$ were infected with Jejuni Campylobacter. The report by Ghafir et al. ${ }^{17}$ suggests that contamination of broiler chicken liver distributed in Belgium capital from 1997 to 1998 was about $68 / 7 \%$. The chicken liver infection rate in 1997 and 1998 were 61/7\% (74 from 120) and 74/6\% (106 from 143). ${ }^{15}$ Sallam et al. ${ }^{20}$ (2007) reported the contamination of meat and edible offal for chicken from 40 to 77 for breast, thighs, wings, liver, gizzard and heart as $64 / 4 \%, 70 \%$, $77 / 1 \%, 64 \%, 45 \%$ and $40 \%$, respectively.

Suzuki and Yammamato (2009) reported the contamination of chicken meat, gizzard, liver and heart as $59 \%, 62 / 2 \%, 62 / 3 \%$ and $33 / 3$, respectively. ${ }^{6}$ In both studies similar to result of this study, the highest infection rates was in liver and the lowest was observed in heart. The reason could be due to liver greater contact area than the heart and its further manipulation. The differences between the results reported from different parts could be attributed to the poultry infection rates in different regions, the interval between studies, the difference in the killing and hygiene practices during different slaughtering phases, sampling seasons and sensitivity of testing methods.
The results showed that among the isolated Campylobacter, the Jejuni type was the most prevalent $(78 / 4 \%)$ and the rest were of Coli type $(21 / 6 \%)$. Other studies have also shown that Jejuni type is the most common species in food with animal origin. $^{6-8,14,17,21}$ For example, in a study by Hussain et al. ${ }^{14}$ (2007) the prevalence of Campylobacter species (Jejuni and Coli) in food samples with animal origin was 70/6\% and $29 / 4 \%$, respectively. The same study reported the prevalence of Jejuni and Coli Campylobacter in chicken as, $72 \%$ and $28 \%$, in sheep meat as $65 \%$ and $35 \%$ and in cow meat as $79 \%$ and $21 \%$, respectively.

Another similar study in 2004 was conducted in Ireland by Whyte et al. ${ }^{13}$ focusing on Jejuni and Coli Campylobacter in food with animal origin which revealed the fact that the contamination level for Jejuni and Coli type were 3804 and 16/6, respectively. The prevalence of bacteria in chicken as $6 / 84$ and $6 / 16 \%$ have been reported.

Moreover, evaluating the Campylobacter contamination in poultry meat samples in different season showed there existed a significant difference in contamination level in summer $(50 / 0>\mathrm{P})$ than in other seasons which was also confirmed by reports from other studies. ${ }^{12}$ Such high prevalence could be attributed to high temperature creating favorable conditions for the bacteria growth of and transferring of infection by insects. The overall results of this study on chicken meat and its edible offal contamination to Campylobacter species showed that a relatively high number of samples especially the liver were infected with this pathogen. Therefore, in order to reduce contamination of chicken meat and its edible products to Campylobacter species and similar microorganisms, maintaining individual health, preserving sanitation in slaughterhouses, following HACCP principles in poultry chains, minimizing the carcasses contact with the edible offal, minimizing the chicken carcasses contact and maintaining the least manipulation and drinking water in slaughtering process seem to be the most important. Also, maintaining hygiene practices in splitting, packaging, and transportation stages and maintaining the cold condition in meat preserving chain until being delivered to consumer serve as very important measures in reducing meat contamination to such pathogens.

Table 2. The contamination of chicken meat and its related edible offal to Campylobacter and its species.

\begin{tabular}{lcccc} 
Samples & Number & $\begin{array}{c}\text { Positive number (\%) } \\
\text { campylobacter infection }\end{array}$ & $\begin{array}{c}\text { Positive number (\%) } \\
\text { campylobacter jejuni infection }\end{array}$ & $\begin{array}{c}\text { Positive number (\%) } \\
\text { campylobacter coli infection }\end{array}$ \\
Meat & 138 & $35(4 / 25)$ & $32(4 / 91)$ & $3(6 / 8)$ \\
Liver & 138 & $68(2 / 49)$ & $61(7 / 89)$ & $7(3 / 10)$ \\
\hline Gizzard & 138 & $59(8 / 42)$ & $53(8 / 89)$ & $6(2 / 10)$ \\
Hearts & 138 & $46(3 / 33)$ & $42(3 / 91)$ & $4(7 / 8)$ \\
\hline
\end{tabular}

Table 3. Monthly contamination of chicken meat and its related edible offal to Campylobacter and its species.

\begin{tabular}{lcccc} 
Samples & Number & $\begin{array}{c}\text { Positive number (\%) } \\
\text { campylobacter infection }\end{array}$ & $\begin{array}{c}\text { Positive number (\%) } \\
\text { campylobacter jejuni infection }\end{array}$ & $\begin{array}{c}\text { Positive number (\%) } \\
\text { campylobacter coli infection }\end{array}$ \\
March & 92 & $29(6 / 31)$ & $23(3 / 79)$ & $6(7 / 20)$ \\
April & 92 & $32(8 / 34)$ & $25(1 / 78)$ & $7(9 / 21)$ \\
May & 92 & $34(37)$ & $26(5 / 76)$ & $8(5 / 23)$ \\
June & 92 & $35(38)$ & $28(80 \%)$ & $7(20)$ \\
\hline July & 92 & $37(2 / 40)$ & $29(4 / 78)$ & $8(6 / 21)$ \\
August & 92 & $41(6 / 44)$ & $32(78)$ & $9(22)$ \\
\hline
\end{tabular}

Table 4. Seasonal contamination of chicken meat and its related edible offal to Campylobacter and its species.

\begin{tabular}{lcccc} 
Samples & Number & $\begin{array}{c}\text { Positive number (\%) } \\
\text { campylobacter infection }\end{array}$ & $\begin{array}{c}\text { Positive number (\%) } \\
\text { campylobacter jejuni infection }\end{array}$ & $\begin{array}{c}\text { Positive number (\%) } \\
\text { campylobacter coli infection }\end{array}$ \\
Spring & 276 & $95(4 / 34)$ & $74(9 / 77)$ & $21(1 / 22)$ \\
Summer & 276 & $113(9 / 40$ & $89(8 / 78)$ & $24(2 / 21)$ \\
\hline Total & 552 & $208(7 / 37)$ & $163(4 / 78)$ & $45(6 / 21)$ \\
\hline
\end{tabular}




\section{References}

1. Bolton FJ, Wareing DR, Skirrow MB, Hutchinson DN. Identification and biotyping of Campylobacter. In: Board GR, Jones D, Skinner FA. Identification methods in applied and environmental microbiology. Society for Applied Microbiology, Technical Series 29. Oxford: Blackwell Scientific Publications; 1992. pp 151-161.

2. Razavilar V. Pathogenic microorganisms in foods and epidemiology food poisoning, University of Tehran Press. 2002.

3. Hassanzadeh P, Motamedifar M. Occurrence of Campylobacter jejuni in Shiraz, Southwest Iran. Med Princ Pract 2007; 16:59-62.

4. Mateo E, Carcamo J, Urquijo M, et al. Evaluations of a PCR assay for the detection and identification of Campylobacter jejuni and Campylobacter coli in retail poultry products, Res Microbiol 2005;156:56874.

5. Frederick A, Huda N. Campylobacterin poultry: incidences and possible control measures. Res J Microbiol 2011;6:18292.

6. Suzuki H, Yamamoto S. Campylobacter contamination in retail poultry meats and by-products in Japan: a literature survey. J Vet Med Sci 2009;71:255-61.

7. Rahimi E, Ameri M. Antimicrobial resistance patterns of Campylobacter spp. isolated from raw chicken, turkey, quail, partridge, and ostrich meat in Iran. Food Control 2011;22:1165-70.
8. Rahimi E, Tajbakhsh E. Prevalence of Campylobacter species in poultry meat in the Esfahan city, Iran. Bulgar J Vet Med 2008;11:257-62.

9. Soltan Dallal MM, Doyle MP, Rezadehbashi M, et al. Prevalence and antimicrobial resistance profiles of Salmonella serotypes, Campylobacter and Yersiniaspp. Isolated from retail chicken and beef, Tehran, Iran. Food Control 2010;21:388-92.

10. Taremi M, Soltan Dallal MN, Gachkar L, et al. Prevalence and antimicrobial resistance of Campylobacter isolated from retail raw chicken and beef meat, Tehran, Iran. International J Food Microbiol 2006;108:401-3.

11. Han K, Jang SS, Choo E, et al. Prevalence, genetic diversity, and antibiotic resistance patterns of Campylobacter jejuni from retail raw chickens in Korea. Int J Food Microbiol 2007;114:50-9.

12. Valdivieso-Garcia A, Harris K, Riche E, et al. Novel Campylobacter isolation method using hydrophobic grid membrane filter and semisolid medium. J Food Protection 2007;70:355-62.

13. Whyte P, McGill K, Cowley D, et al. Occurrence of Campylobacter in retail foods in Ireland. Int J Food Microbiol 2004;95:111-8.

14. Hussain I, Mahmood MS, Akhtar M, Khan A. Prevalence of Campylobacter species in meat, milk and other food commodities in Pakistan. Food Microbiol 2007;24:219-22.

15. Gonzalez I, Grant KA, Richardson PT, et al. Specific identification of the enteropathogens Campylobacter jejuni and Campylobacter coli using PCR test based on the ceuEgene encoding a putative virulence determinant. J Clin Microbiol 1997;35:759-63.

16. Denis M, Soumet C, Rivoal K, et al. Development of a m-PCR for simultaneous identification of Campylobacter jejuni and C. coli. Lett Appl Microbiol 1999;29:406-10.

17. Ghafir Y, China B, Dierick K, et al. A seven-year survey of Campylobacter contamination in meat at different production stages in Belgium. Int J Food Microbiol 2007;116:111-20.

18. Yildirim M, Istanbulluoglu E, Ayvali B. Prevalence and antibitoic susceptibility of thermophilic Campylobacter species in broiler chickens. Turk J Vet Anim Sci 2005;29:655-60.

19. Shakerian A, Rokni N, Sharifzadeh A, et al. Campylobacter jejuna's a potential pathogen in liver of broilers chickens in slaughtered and retail market broilers in Shahr-e-Kord, Iran. Iran J Food Sci Technol 2005;1:43-50.

20. Sallam KI. Prevalence of Campylobacter in chicken and chicken by-products retailed in Sapporo ares, Hokkaido, Japan. Food Control 2007;18:1113-20.

21. Franchin PR, Ogliari PJ, Batista CRV. Frequency of thermophilic Campylobacter in broiler chickens during industrial processing in a Southern Brazil slaughterhouse. Br Poultry Sci 2007;48:127-32. 